\title{
Exploration of the active phase of the hydrotalcite-derived cobalt catalyst for $\mathrm{HCHO}$ oxidation
}

\author{
Mengya Lin a,b, Xiaolin Yu a,b,*, Xueqin Yang a,b, Xiuyun Ma ${ }^{\text {a,b }}$, Maofa Ge a,b,c,\# \\ a State Key Laboratory for Structural Chemistry of Unstable and Stable Species, Beijing National Research Center for Molecular Sciences (BNLMS), CAS \\ Research/Education Center for Excellence in Molecular Sciences, Institute of Chemistry, Chinese Academy of Sciences, Beijing 100190, China \\ b University of Chinese Academy of Sciences, Beijing 100049, China \\ c CAS Center for Excellence in Regional Atmospheric Environment, Institute of Urban Environment, Chinese Academy of Sciences, Xiamen 361021, Fujian, \\ China
}

\section{A R T I C L E I N F O}

\section{Article history:}

Received 17 October 2018

Accepted 5 December 2018

Published 5 May 2019

\section{Keywords:}

$\mathrm{HCHO}$

Hydrotalcite derivate

Active phase

Cobalt oxide

\begin{abstract}
A B S T R A C T
A series of Co-based oxide catalysts were prepared by calcining hydrotalcite precursors in different atmospheres and studied for $\mathrm{HCHO}$ catalytic oxidation. The $\mathrm{N}_{2}$-calcined catalyst exhibits enhanced $\mathrm{HCHO}$ oxidation and superior stability. On the basis of $\mathrm{H}_{2}$-TPR, X-ray photoelectron spectroscopy, and Raman characterizations, this can be ascribed to better redox ability, octahedrally coordinated $\mathrm{Co}^{2+}$ ions derived from the $\mathrm{CoO}$ phase, and other surface oxygen species, such as $\mathrm{O}_{2}{ }^{-}$or $\mathrm{O}^{-}$. The extra octahedrally coordinated $\mathrm{Co}^{2+}$ ions may reside in a more open framework site than the inactive tetrahedrally coordinated $\mathrm{Co}^{2+}$ ions. This species of $\mathrm{Co}^{2+}$ can easily make contact with oxygen and oxidize. The surface oxygen species, along with the octahedrally coordinated $\mathrm{Co}^{2+}$ ions, and a part of the $\mathrm{Co}^{3+}$ species constitute the $\mathrm{Co}^{2+}$-oxygen species- $\mathrm{Co}^{3+}$ sites, which enhance the catalytic activities. According to DRIFTS, $\mathrm{Co}^{2+}$-oxygen species- $\mathrm{Co}^{3+}$ makes oxidation of $\mathrm{HCHO}$ and conversion of DOM to formate easier.
\end{abstract}

(C) 2019, Dalian Institute of Chemical Physics, Chinese Academy of Sciences. Published by Elsevier B.V. All rights reserved.

\section{Introduction}

HCHO is a harmful indoor volatile organic compound because long-term exposure to $\mathrm{HCHO}$ atmosphere even at a low concentration can cause severe health problems, such as eye irritation, skin irritation, headache, and even cancer [1-3]. HCHO has extensive sources available across our daily lives. For example, it is released from wood-based building products, decorative materials, coatings, and even motor vehicles. It has become a major indoor pollutant in recent years [4]. Furthermore, methods to mitigate this major pollutant has gained sig- nificant attention. Among all the existing removal methods, catalytic oxidation is regarded as the most effective method because of its high removal efficiency, harmless final products, and long-time effectiveness [4-7].

Transition metal oxides, especially Co-based oxides, usually exhibit excellent HCHO catalytic ability because of their multiple valence states and wide range of sources. Much research has been conducted to synthesize and modify Co-based materials to develop a promising material. González-Prior et al. [8] enlarged the specific surface area of $\mathrm{Co}_{3} \mathrm{O}_{4}$ using the SBA-15 hard template. Zhou et al. [9] prepared Cu-substituted

\footnotetext{
* Corresponding author. Tel/Fax: +86-10-62554518; E-mail: icecoolyu@iccas.ac.cn

\# Corresponding author. Tel/Fax: +86-10-62554518; E-mail: gemaofa@iccas.ac.cn

This work was support by the National Natural Science Foundation of China (91544227, 21777166) and the National Key R\&D Program of China (2016YFC0202202).

DOI: S1872-2067(19)63273-0 | http://www.sciencedirect.com/science/journal/18722067 | Chin. J. Catal., Vol. 40, No. 5, May 2019
} 
$\mathrm{Co}_{3} \mathrm{O}_{4}-\mathrm{Cu}_{\mathrm{x}}$ by replacing a certain amount of $\mathrm{Co}^{2+}$ with $\mathrm{Cu}^{2+}$. The modified materials exhibited enhanced $\mathrm{CO}$ oxidation ability. Bai et al. [4] prepared nano- $\mathrm{Co}_{3} \mathrm{O}_{4}, 2 \mathrm{D}-\mathrm{Co}_{3} \mathrm{O}_{4}$, and $3 \mathrm{D}-\mathrm{Co}_{3} \mathrm{O}_{4}$ catalysts and observed that these types of $\mathrm{Co}_{3} \mathrm{O}_{4}$ could influence the $\mathrm{HCHO}$ catalytic oxidation ability, with $3 \mathrm{D}-\mathrm{Co}_{3} \mathrm{O}_{4}$ exhibiting the best performance. Besides, research on exploring the reason for the high catalytic ability of Co-based materials has also been conducted, and remarkable achievements have been obtained. Omata et al. [10] observed that during the $\mathrm{CO}$ oxidation process, $\mathrm{Co}^{3+}$ significantly influences the catalytic performance while $\mathrm{Co}^{2+}$ is useless. Mo et al. [11] discovered that high-valence Co ions are the main active sites during the benzene hydrocarbon combustion process, because they can induce more surface Lewis acidic sites and enhance the reducibility of the catalyst. Some studies reported that $\mathrm{Co}_{3} \mathrm{O}_{4}$ facets, mainly composed of $\mathrm{Co}^{3+}$ on the surface of $\mathrm{Co}_{3} \mathrm{O}_{4}$, are the main active sites for $\mathrm{HCHO}$ catalytic oxidation [12]. The amount of surface oxygen vacancies and different exposed crystal planes have also been explored and considered as essential factors affecting the catalytic process. Yu et al. $[13,14]$ desired $\mathrm{Co}_{3} \mathrm{O}_{4}$ treated at a moderate temperature. They believed that the high $\mathrm{CO}$ catalytic performance and relatively long time stability are related to the abundant surface oxygen vacancies. Hu et al. [15] prepared several $\mathrm{Co}_{3} \mathrm{O}_{4}$ nanocrystals with different exposed planes that exhibited different activity order for methane in the order of $\{112\}>\{011\}>\{001\}$. These results imply that Co-based catalysts are promising materials and Co-based oxides can be developed further in the field of catalytic oxidation.

Previous studies proved that different calcination atmospheres greatly influence the surface chemical properties of the catalysts. Ku's et al. [16] operated MgO in different atmospheres, such as nitrogen, oxygen, nitrogen-oxygen mixture, and helium. They discovered that the catalysts operating in oxygen-enriched atmosphere exhibited lower surface basicity, which gave lower methane conversion than the catalysts operating in the inert atmosphere. Galetti et al. [17] prepared a series of $\mathrm{Ni} / \mathrm{ZnAl}_{2} \mathrm{O}_{4}$ catalysts calcined in reductive and oxidative atmospheres. They observed that the reductive atmosphere enhanced the ethanol steam reforming activity and stability. Zou et al. [18] evaluated the catalytic effects of different $3 \mathrm{Fe} 8 \mathrm{Ni} / \mathrm{PG}$ products operated under different calcination conditions including different calcination temperatures, times, and atmospheres. These results proved that the catalyst reduced in $\mathrm{H}_{2}$ exhibited better catalytic performance than the catalyst calcined in air. The characterization results indicated that different managing processes could create different compositions, thereby leading to different catalytic performances. It can be concluded that the calcination method plays a key role in adjusting the properties of the catalyst.

In this study, we prepared a series of Co-based oxides calcined in different atmospheres. The HCHO oxidization mechanism is presented according to the various characterization methods. From the X-ray photoelectron spectroscopy (XPS), Raman spectroscopy, and $\mathrm{H}_{2}$-TPR results, the $\mathrm{Co}^{2+}$ and oxygen vacancies can greatly influence its activity in this system. This is because the $\mathrm{N}_{2}$ calcination process is conducive to the generation of $\mathrm{CoO}$, which is related to the more octahedrally coordi- nated $\mathrm{Co}^{2+}$ species. Besides, the $\mathrm{N}_{2}$ calcined catalysts also enhanced the surface $\mathrm{O}_{2}{ }^{-}$and $\mathrm{O}^{-}$content. Based on the XPS and DRIFT experiments, the HCHO molecule in an oxygen-deficit environment will be adsorbed on the surface of the catalyst. When abundant oxygen was introduced over the catalyst, $\mathrm{HCHO}$ will be oxidized into dioxymethylene (DOM) and formate by $\mathrm{O}_{2}^{-}$or $\mathrm{O}^{-}$. When the oxygen species get consumed, the vacancy would be replenished by dissociating the oxygen gas. Thus, it can be proposed that both octahedrally coordinated $\mathrm{Co}^{2+}$ species and surface oxygen species are the key factors that influence the HCHO degradation ability.

\section{Experimental}

\subsection{Synthesis procedure}

The Co(II)Co(III)LDH precursor was first prepared by a hydrothermal method stated in previous reports $[11,18]$. In a typical synthetic process, $20 \mathrm{~mL} 1.0 \mathrm{~mol} \mathrm{~L}^{-1} \mathrm{Co}\left(\mathrm{NO}_{3}\right)_{2} \cdot 6 \mathrm{H}_{2} \mathrm{O}$

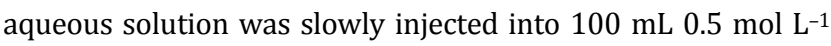
ammonia solution with vigorous magnetic stirring at $40{ }^{\circ} \mathrm{C}$. The mixture was kept at this temperature for $48 \mathrm{~h}$ with purified oxygen gas bubbling. The resultant product was then washed several times with deionized water, followed by drying in an oven at $70{ }^{\circ} \mathrm{C}$. Before being used in the catalytic experiments, the powders were calcined at $400{ }^{\circ} \mathrm{C}$ under $\mathrm{N}_{2}$ or air for $4 \mathrm{~h}$. The resultant products were denoted as Co-LDO(N) or Co-LDO, respectively. A similar method was used to obtain CoMg-LDO(N) and CoMg-LDO, although an appropriate amount of $\mathrm{Mg}\left(\mathrm{NO}_{3}\right)_{2} \cdot 6 \mathrm{H}_{2} \mathrm{O}$ was added [19]. CoMg-LDO(N) and CoMg-LDO were prepared to obtain a type of contrast material with larger area [20,21]. A transition metal with multiple valence states exhibits better catalytic abilities, while the Mg element is considered to be inactive. It is difficult for $\mathrm{Mg}$ to show better redox ability because of the single valence. Thus, the addition of Mg could increase the BET surface area without introducing other active sites.

\subsection{Material characterization}

The X-ray diffraction (XRD) patterns of the powder were recorded on a Rigaku D/MAX 2500 using monochromatized $\mathrm{Cu}$ $\mathrm{K}_{\alpha}$ radiation from $3^{\circ}$ to $80^{\circ}$ at a scanning speed of $4^{\circ} \mathrm{min}^{-1}$. The morphologies and sizes were determined by a Hitachi S-4800 scanning electron microscope (SEM). High-resolution transmission electron microscopy (HRTEM) was conducted to investigate the microstructure. To detect the specific surface areas and pore sizes of the samples, BET experiments were characterized on an AUTOSORB-IQ instrument. Prior to $\mathrm{N}_{2}$ adsorption-desorption measurement, each sample was degassed with $\mathrm{N}_{2}$-purged at $100{ }^{\circ} \mathrm{C}$ for $10 \mathrm{~h}$. XPS measurements were performed on a VG ESCALAB250XI. The binding energies were corrected by setting the binding energy of the $\mathrm{C} 1 s$ to $284.8 \mathrm{eV}$. The Raman spectra of the samples were obtained on a LabRAM Aramis Raman spectrometer (HORIBA Jobin Yvon S. A. S.) equipped with a $532 \mathrm{~nm}$ laser. For the $\mathrm{H}_{2}$-TPR analysis, $100 \mathrm{mg}$ samples were pretreated in $\mathrm{N}_{2}$ at $300^{\circ} \mathrm{C}$ for $1 \mathrm{~h}$ and then cooled 
to room temperature. Further, the temperature was set from room temperature to $700{ }^{\circ} \mathrm{C}$ by heating it at a rate of $10{ }^{\circ} \mathrm{C}$ min $^{-1}$. The reducing gas flow was $5 \% \mathrm{H}_{2}$ in $\mathrm{N}_{2}$. The in situ DRIFTS spectra were collected using a Nicolte iS50. In a typical process, $100 \mathrm{ppm} \mathrm{HCHO}$ and $20 \mathrm{vol} \% \mathrm{O}_{2}$ balanced with $\mathrm{N}_{2}$ were fed over a certain amount of sample.

\subsection{Catalyst activity}

The activities of the catalysts for HCHO catalytic oxidation were tested in a fixed-bed quartz tube reactor (inner diameter $=4 \mathrm{~mm}$ ), and the reaction conditions were controlled as follows. A steady gas reactant mixture containing $100 \mathrm{ppm} \mathrm{HCHO}$ and 20.0 vol\% $\mathrm{O}_{2}$ balanced with $\mathrm{N}_{2}$ flowing at $100 \mathrm{~mL} \mathrm{~min}^{-1}$ was passed through an $80 \mathrm{mg}$ fresh catalyst. The HCHO gas was generated by passing $\mathrm{N}_{2}$ through a paraformaldehyde incubator at $37.5^{\circ} \mathrm{C}$. All the outlet gases were analyzed using an online Agilent 7890B gas chromatograph equipped with a TCD detector, and the type of chromatographic column used was HP-PLOT/Q+PT from Agilent. The catalytic activity for HCHO oxidation was evaluated in terms of $\mathrm{CO}_{2}$ concentration according to the carbon balance; the specific formula was HCHO conversion $=C_{\mathrm{CO} 2} / C_{\mathrm{HCHO}} \times 100 \%$, where $C_{\mathrm{CO} 2}$ is the outlet concentration of $\mathrm{CO}_{2}$ and $\mathrm{C}_{\mathrm{HCHO}}$ refers to the inlet concentration of HCHO.

\section{Results and discussion}

The XRD patterns of the as-prepared catalysts are shown in Fig. 1. All the samples without calcination show typical reflections of hydrotalcites, and no other crystalline phases can be detected, thereby indicating the pure phase of the product $[22,23]$. After calcination, the diffraction peaks of all the products in Fig. 1(b) can be indexed as a spinel structure with $2 \theta$ values of $18.8^{\circ}, 31.0^{\circ}, 36.6^{\circ}, 44.5^{\circ}, 59.0^{\circ}$, and $65.0^{\circ}$, corresponding to (111), (220), (311), (400), (511), and (440) crystal planes of $\mathrm{Co}_{3} \mathrm{O}_{4}$, respectively $[19,24]$. The patterns of the pure Co oxides exhibit more sharp and symmetric peaks, which strongly suggest that these phases were better crystallized.

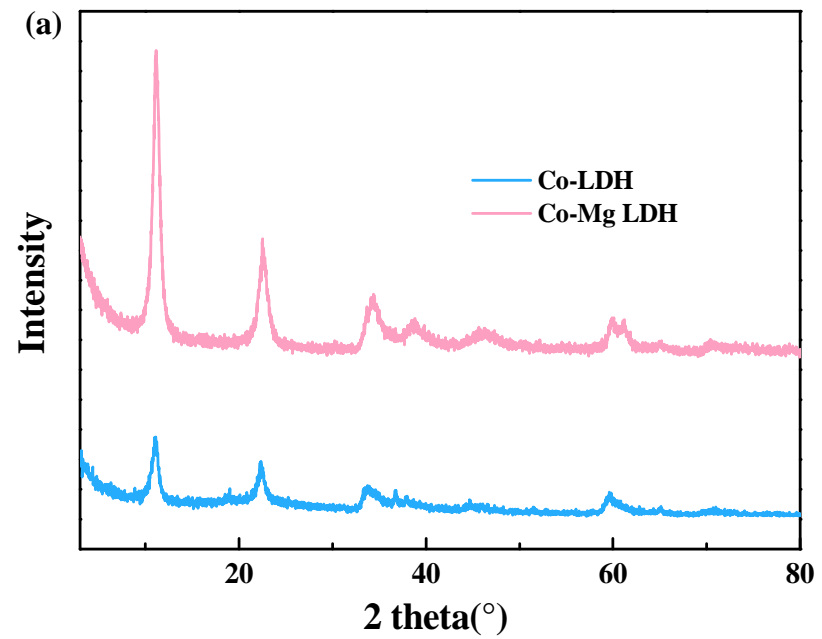

Table 1

Surface element value states and specific surface areas of the as-prepared samples.

\begin{tabular}{lccc}
\hline Catalyst & $A_{\text {BET }}\left(\mathrm{m}^{2} / \mathrm{g}\right)$ & $\mathrm{O}_{\text {ads }} / \mathrm{O}_{\text {latt }}{ }^{-}$ & $\mathrm{CoO}^{-} \mathrm{Co}_{3} \mathrm{O}_{4}$ \\
\hline Co-LDO(N) & 61 & 1.72 & 0.16 \\
CoMg-LDO(N) & 234 & 1.72 & 0.17 \\
Co-LDO & 38 & 1.53 & 0.07 \\
CoMg-LDO & 101 & 1.45 & 0.03 \\
Co-LDO(N) used & - & - & 0.15 \\
\hline
\end{tabular}

Besides, the interfusion of Mg doesn't induce additional peaks, indicating the relatively low amount of $\mathrm{Mg}$ or the amorphous $\mathrm{MgO}$ phase. Although there are no changes in the crystalline phase, the specific surface areas increase with the incorporation of $\mathrm{Mg}$, as presented in Table 1. A previous study discovered that the incorporation of second metal ions can influence the crystallization process, which can decrease the particle size and increase the BET value [21]. Besides, low-temperature calcination may also help prevent the sample from recrystallizing. All these may explain the relatively high BET values of CoMg hydrotalcite derivative [19].

Figure 2 shows the SEM and HRTEM images. The hydrotalcite derivates exhibit uniform lamellar structure. In contrast, CoMg-LDO(N) and CoMg-LDO exhibit smaller particle sizes because of the inhibition effect caused by the above-mentioned incorporation of $\mathrm{Mg}$ during the crystal growth. The detailed lattice fringes information is given by the HRTEM images. As shown in Figs. 2(e)-2(h), the dominant exposed planes of the samples are calculated to be $\{001\}$, which are the only planes normal to the set of (220) planes with a lattice space of around $0.28 \mathrm{~nm}[15,25]$.

The $\mathrm{H}_{2}$-TPR experiments were performed to investigate the redox ability. As shown in Fig. 3, a two-step reduction process can be observed, which can be attributed to the path of $\mathrm{Co}^{3+} \rightarrow \mathrm{Co}^{2+}$ and $\mathrm{Co}^{2+} \rightarrow \mathrm{Co}^{0}$, respectively [11]. The samples calcined in different atmospheres exhibit conspicuous distinction. Co-LDO(N) and CoMg-LDO(N) samples have a relatively lower reduction temperature than Co-LDO and CoMg-LDO samples, indicating the better redox ability of samples calcined in the

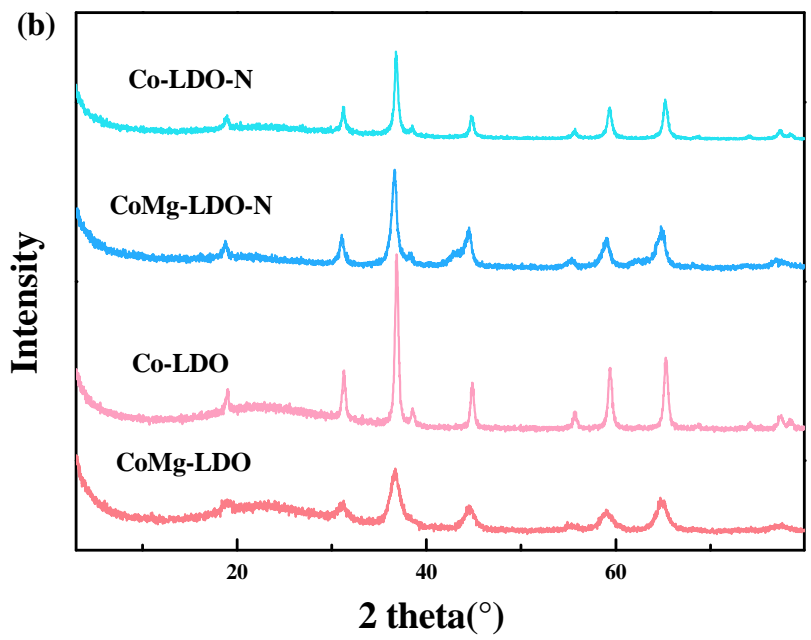

Fig. 1. XRD patterns of (a) Co-based hydrotalcite and CoMg hydrotalcite precursors, and (b) catalysts calcined in different atmospheres. 

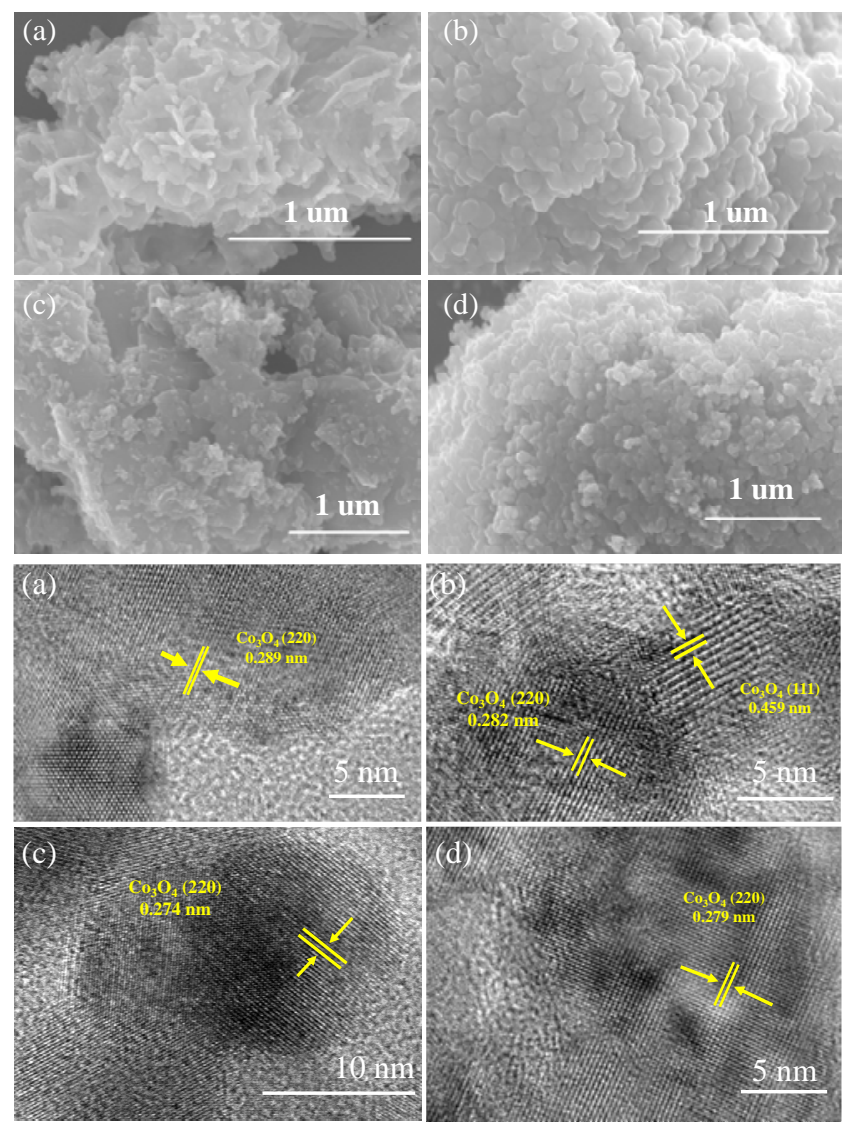

Fig. 2. SEM and HRTEM images of (a, e) Co-LDO(N), (b, f) CoMg-LDO(N) (c, g) Co-LDO, and (d, h) CoMg-LDO.

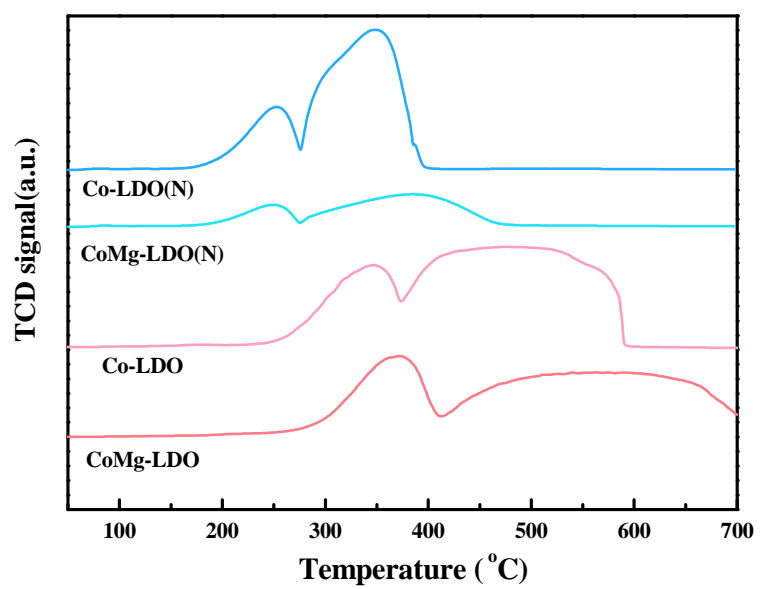

Fig. 3. $\mathrm{H}_{2}$-TPR profiles of Co-LDO(N), CoMg-LDO(N), Co-LDO, and CoMg-LDO.

inert atmosphere. A previous study proved that the shifts toward the lower temperature are caused by the presence of more active oxygen species [1]. Thus, it can be reasonably summarized that the $\mathrm{N}_{2}$ atmosphere is beneficial to the generation of surface active oxygen species. Furthermore, it is noted that in the inert atmosphere the incorporation of $\mathrm{Mg}$ does not deteriorate the redox ability of the samples, while the oxygen atmosphere evokes an increase in the reduction temperature from $348^{\circ} \mathrm{C}$ to $372^{\circ} \mathrm{C}$ by the introduction of $\mathrm{Mg}$.

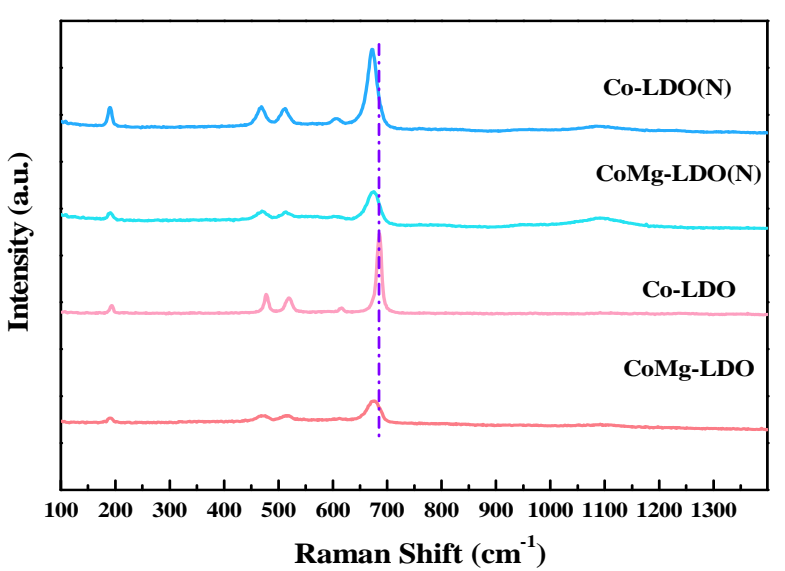

Fig. 4. Raman spectra of Co-LDO(N), CoMg-LDO(N), Co-LDO, and CoMg-LDO.

To investigate the surface information of the samples, Raman signals, shown in Fig. 4, can be observed. Typically, five bands located at 198, 484, 522, 622, and $694 \mathrm{~cm}^{-1}$, which can be assigned to the $\mathrm{F}_{2 \mathrm{~g}}{ }^{1}, \mathrm{E}_{\mathrm{g}}, \mathrm{F}_{2 \mathrm{~g}}{ }^{2}$, and $\mathrm{A}_{1 \mathrm{~g}}$ modes of spinel $\mathrm{Co}_{3} \mathrm{O}_{4}$, respectively, are obtained [26,27]. Accordingly, the peaks banding at $667 \mathrm{~cm}^{-1}$ can be assigned to the octahedral sites, while those at $189 \mathrm{~cm}^{-1}$ can be ascribed to the tetrahedral sites in the standard $\mathrm{Co}_{3} \mathrm{O}_{4}$ types [28]. Comparing the samples calcined in $\mathrm{N}_{2}$ with those in $\mathrm{O}_{2}$, a slight shift toward the lower frequency can be observed for Co-LDO(N) and CoMg-LDO(N). The presence of this red shift can be attributed to the relative abundance of $\mathrm{Co}^{2+}$ and oxygen vacancies $[11,26,29]$. Besides, a wide and weak band at around $1100 \mathrm{~cm}^{-1}$, related to the oxygen vacancies can be observed in both Co-LDO(N) and CoMg-LDO(N) [30]. According to a previous study, the dissociation of gaseous oxygen usually occurs at the oxygen vacancies. The oxygen vacancies influence the improvement of the oxygen mobility and acquirement of the facial method for the active oxygen species [31]. Thus, an oxygen vacancy can be considered as an important oxygen supplements source during the catalytic process [32]. Accordingly, the concentration of oxygen vacancies is related to the oxidation ability of the catalysts. In Fig. 3, it can be observed that the catalysts calcined in $\mathrm{N}_{2}$ possess more oxygen vacancies, demonstrating that Co-LDO(N) and CoMg-LDO(N) have better catalytic ability.

Surface element analysis tests were conducted to detect the surface valence states, as shown in Fig. 5. According to the binding energy and the intensities of the shake-up peaks, a plateau can be observed, indicating the existence of both $\mathrm{CoO}$ and $\mathrm{Co}_{3} \mathrm{O}_{4}$ [33]. In addition, by deconvoluting the Co $2 p_{3 / 2}$ signals, the materials were well fitted with the mixture of $\mathrm{Co}_{3} \mathrm{O}_{4}$ (pink curve) and $\mathrm{CoO}$ (blue curve) [34], and the specific $\mathrm{CoO} / \mathrm{Co}_{3} \mathrm{O}_{4}$ values are calculated and listed in Table 1 . It can be seen that the $\mathrm{CoO} / \mathrm{Co}_{3} \mathrm{O}_{4}$ values of $\mathrm{Co}-\mathrm{LDO}(\mathrm{N})$ and CoMg-LDO $(\mathrm{N})$ are 0.16 and 0.18 , respectively, which are higher than those of Co-LDO and CoMg-LDO. The $\mathrm{N}_{2}$ calcination process created more surface $\mathrm{CoO}$ species, which means that more $\mathrm{Co}^{2+}$ ions exist on the surface [35-38]. $\mathrm{Co}^{2+}$ ions are generally considered to be inactive during the catalytic performance. 

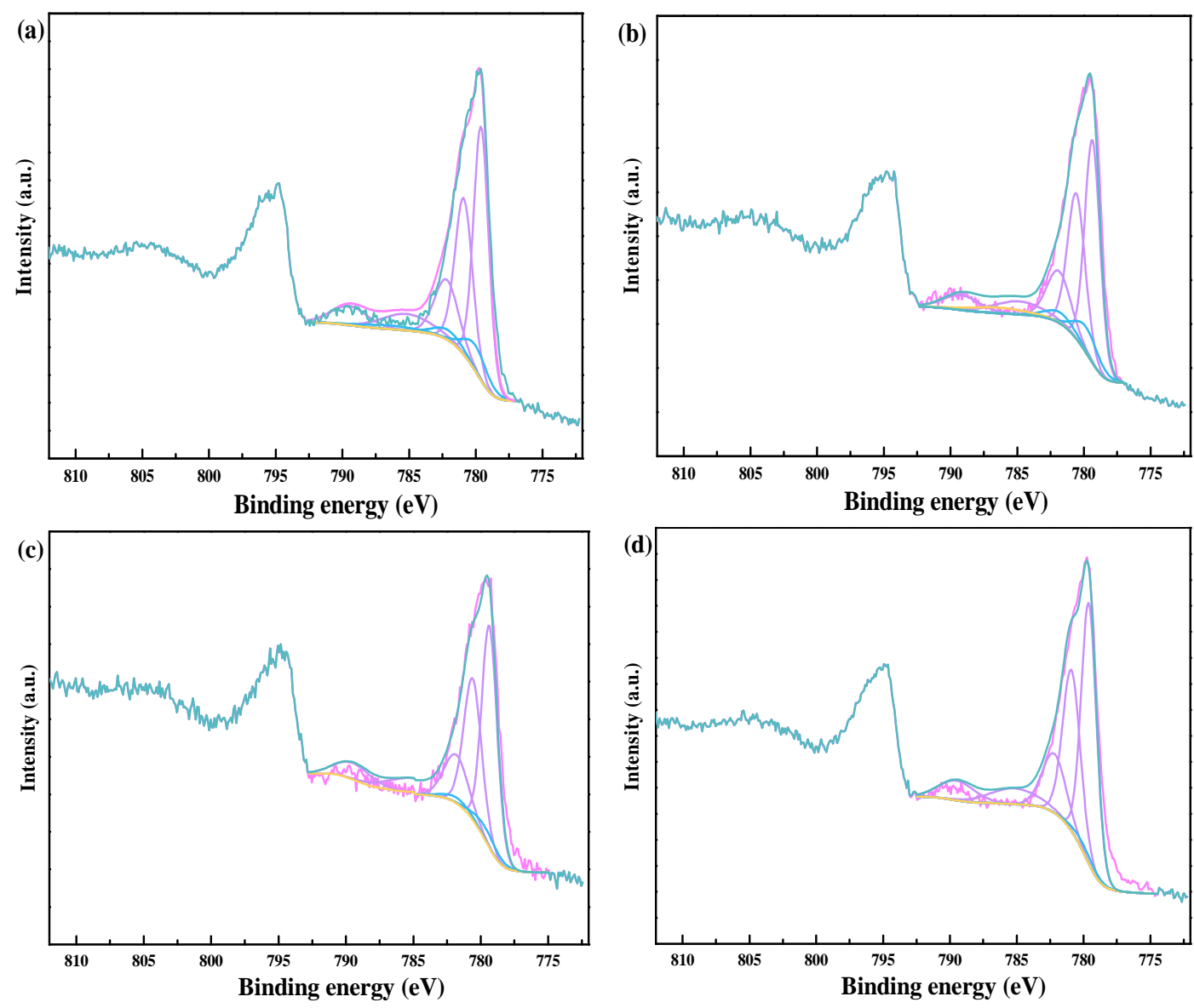

Fig. 5. Co $2 p$ XPS spectra of (a) Co-LDO(N), (b) CoMg-LDO(N), (c) Co-LDO, and (d) CoMg-LDO.

However, Schüth et al. [33] discovered that the rock-salt structure of $\mathrm{CoO}$ with a single $\mathrm{Co}^{2+}$ ion octahedrally coordinated by lattice oxygen can exhibit very high catalytic abilities for CO. In contrast to the inactive tetrahedrally coordinated $\mathrm{Co}^{2+}$ ion, the octahedrally coordinated $\mathrm{Co}^{2+}$ ion is more open and more easy to oxidize. The octahedrally $\mathrm{Co}^{2+}$ sites in $\mathrm{CoO}$ are similar to the $\mathrm{Co}^{3+}$ sites in $\mathrm{Co}_{3} \mathrm{O}_{4}$, and may have higher surface density if $\mathrm{Co}^{2+}$ is oxidized.

The XPS spectra of $01 s$ in Fig. 6 consist of three peaks at 529.7, 531.7, and 534.4 eV, corresponding to lattice oxygen atoms (Olatt) in the bulk $\mathrm{Co}_{3} \mathrm{O}_{4}$, surface chemisorbed oxygen including $\mathrm{O}^{-}$and $\mathrm{O}_{2^{-}}\left(\mathrm{O}_{\mathrm{ads}}\right)$, and oxygen-containing (hydro)carbons, respectively [34,39-41]. It can be seen in Table 1 that the samples calcined in $\mathrm{N}_{2}$ exhibit relatively higher content of surface adsorbed oxygen species. Combining this with the Co $2 p$ XPS results, it can be deduced that a relatively high surface oxygen species should be produced by the oxygen vacancies, because oxygen vacancies would be generated to maintain the electrostatic balance when the reduced element states exist as discussed earlier [42]. The O XPS results are consistent well with the Raman results [40]. Thus, it can be speculated that a relatively high concentration of surface adsorbed oxygen may enhance the catalytic performance greatly.

HCHO catalytic oxidation experiments were conducted to evaluate the catalytic ability. In Fig. 7(a), it is clear that
Co-LDO(N) and CoMg-LDO(N) exhibit the best catalytic performance. The complete conversion of $\mathrm{HCHO}$ occurs at $125{ }^{\circ} \mathrm{C}$, about $10{ }^{\circ} \mathrm{C}$ and $30{ }^{\circ} \mathrm{C}$ higher than that of Co-LDO and CoMg-LDO, respectively. Combining the Raman and Co $2 p$ XPS results, the calcination in the $\mathrm{N}_{2}$ atmosphere can provide the $\mathrm{CoO}$ species and possess more vacancies. A previous study discovered that $\mathrm{Co}_{3} \mathrm{O}_{4}$ pretreated in the inert atmosphere could enhance the formation of oxygen vacancies [13]. The abundant oxygen vacancies can provide more surface oxygen species, such as $\mathrm{Co}^{3+-} \mathrm{O}_{2}{ }^{-}-\mathrm{Co}^{2+}$, and the $\mathrm{O}_{2}{ }^{-}$species can further dissociate into $\mathrm{O}^{-}$to form $\mathrm{Co}^{3+-} \mathrm{O}^{-}-\mathrm{Co}^{2+}$, which is the key active oxygen species during the oxidation reaction [13]. This agrees well with our $01 s$ XPS and Raman results, in which more oxygen species are observed on the surface of Co-LDO(N) and CoMg-LDO(N). The surface oxygen species play important roles in the oxidation reactions because they can react with the adsorbed reactants directly, and their mobilities are better than that of the lattice oxygen species [42-44]. Thus, the relatively high surface oxygen content created by the $\mathrm{Co}^{2+}$ ions is the key factor related to the high activity.

The stability of the catalyst was verified and the result is shown in Fig. 7(b). Typically, the test was conducted at $115^{\circ} \mathrm{C}$ to bring the conversion under $50 \%$. Accordingly, the $\mathrm{HCHO}$ conversion was maintained at around $50 \%$ for $30 \mathrm{~h}$. It can be seen that there is less than $10 \%$ decrease during the entire test. 

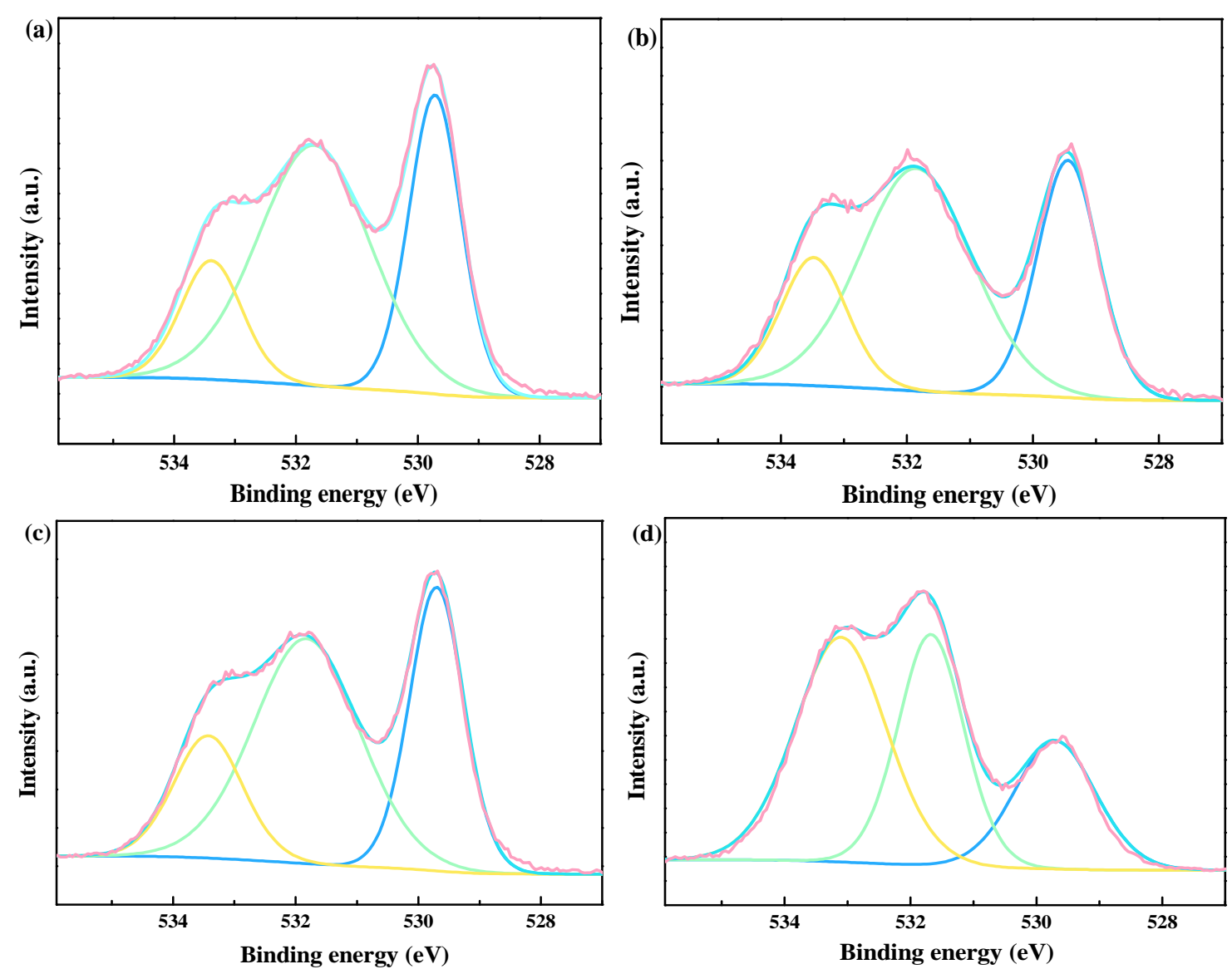

Fig. 6. 0 1s XPS spectra of (a) Co-LDO(N), (b) Co-LDO, (c) CoMg-LDO(N), and (d) CoMg-LDO.
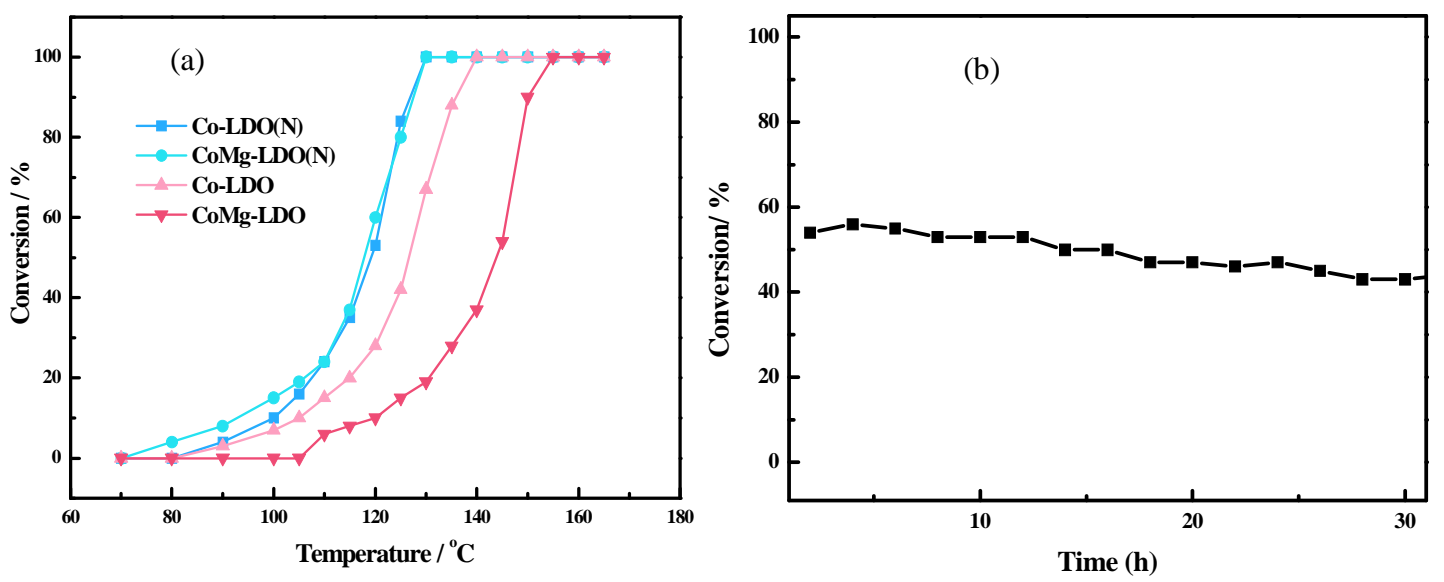

Fig. 7. (a) HCHO conversion over Co-LDO(N), CoMg-LDO(N), Co-LDO, and CoMg-LDO; (b) Stability of HCHO conversion over Co-LDO(N) at $115{ }^{\circ} \mathrm{C}$.

The slight decrease may be because of the accumulation of carbonates. In general, the Co-LDO(N) catalyst exhibits excellent stability and shows potential application value.

To better understand the specific reaction path of the enhanced catalytic ability over the Co-LDO(N) catalyst, the in situ DRIFT experiments were performed to detect the mechanism. As shown in Fig. 8(a), two main peaks at 1581 and $1359 \mathrm{~cm}^{-1}$ corresponding to the asymmetric $\mathrm{Vas}(\mathrm{COO})$ and symmetric
Vs(COO) stretch of formate, respectively, can be observed after the exposure to the flow of $\mathrm{O}_{2}+\mathrm{HCHO}+\mathrm{N}_{2}$ [45]. The band at $2840 \mathrm{~cm}^{-1}$ corresponding to the $\mathrm{CH}$ stretch of formate can also be observed [46]. With time, the bands at and $1211 \mathrm{~cm}^{-1}$, which can be ascribed to the carbonate species, appeared [39], indicating the accumulation of carbonate during the oxidation process. It can be inferred that formate and carbonate are two important species during the HCHO oxidation. To detect more 

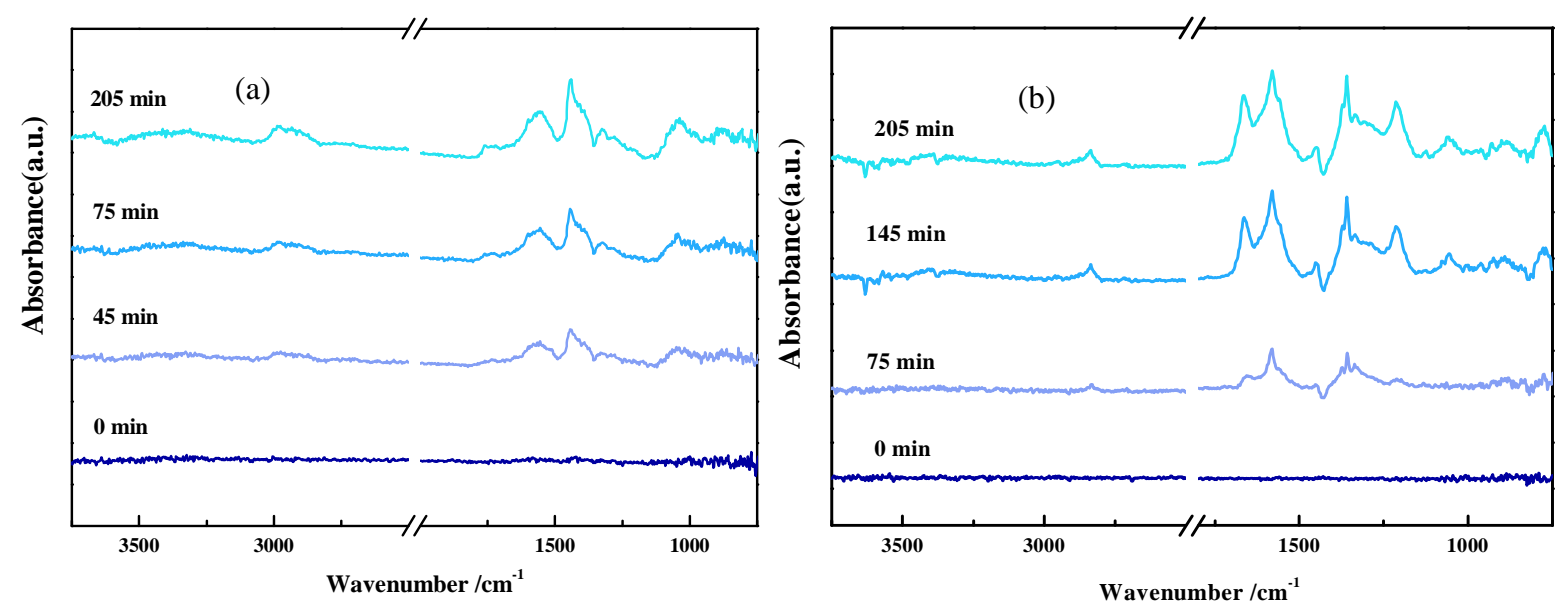

Fig. 8. In situ DRIFT spectra of Co-LDO(N) exposed (a) to the $\mathrm{HCHO}+\mathrm{O}_{2}$ atmosphere and (b) to the $\mathrm{HCHO}$ at $120{ }^{\circ} \mathrm{C}$.

details, Co-LDO(N) was exposed to $\mathrm{HCHO}+\mathrm{N}_{2}$, as shown in Fig. 8(b). The peak at $1755 \mathrm{~cm}^{-1}$ assigned to HCHO is observed, suggesting that the $\mathrm{HCHO}$ would be adsorbed on the surface of the catalyst directly in the anaerobic atmosphere $[47,48]$. Once oxygen is induced into the reaction system, adequate surface $\mathrm{O}_{2}^{-}$or $\mathrm{O}^{-}$are supplied, which promotes the fast occurrence of the HCHO oxidization process. Therefore, we cannot observe $\mathrm{HCHO}$ in the flow of $\mathrm{O}_{2}+\mathrm{HCHO}+\mathrm{N}_{2}$. The peak at around 2986, 1443,1323 , and $1048 \mathrm{~cm}^{-1}$ can be ascribed to DOM [7], which is an important intermediate in the previous discoveries; however, it can be hardly observed in Fig. 8(a). This demonstrates that DOM could be oxidized in a very short time in the oxygen-rich environment. Bands corresponding to formate can also be seen; however, the intensity is relatively weaker as compared to the figure exposed to the oxygen-rich environment. Additionally, no peaks of carbonate can be seen, indicating that only adequate or excess oxygen species can oxidize the intermediate carbonate.

According to the above observation, the XPS and Raman results confirmed that the catalyst calcined in $\mathrm{N}_{2}$ presents relatively higher oxygen vacancy sites. These vacancies are the major active sites for oxygen dissociation, indicating that there can be abundant oxygen species especially active oxygen species $\left(\mathrm{O}_{2}^{-}\right.$and $\left.\mathrm{O}^{-}\right)$on the surface of Co-LDO(N). The excellent redox ability comparing to the sample calcined in $\mathrm{O}_{2}$ is proved by the $\mathrm{H}_{2}$-TPR results. This phenomenon gives the evidence that the $\mathrm{N}_{2}$ calcination is beneficial for the enhancement of the mobility of the surface active oxygen atoms. Combining with the above results, the mechanisms of the enhanced HCHO oxidization ability by $\mathrm{O}_{2}^{-}$and $\mathrm{O}^{-}$are shown in Fig. 9. In Fig. 9(a), $\mathrm{HCHO}$ is first adsorbed on the surface of the octahedrally coordinated $\mathrm{Co}^{2+}$ sites. Further, $\mathrm{O}_{2}^{-}$would oxidize $\mathrm{HCHO}$ into the DOM intermediate. The excellent oxygen mobility would move one oxygen ion toward the surface of the active $\mathrm{Co}^{2+}$ ion to obtain the formate. Subsequently, the formate will be attacked by other oxygen atoms. $\mathrm{CO}_{2}$ and $\mathrm{H}_{2} \mathrm{O}$ will be obtained during this process. The consumption of $\mathrm{O}_{2}{ }^{-}$would result in unsaturated sites, which are the active sites for $\mathrm{O}_{2}$ dissociation [49]. Figure 9(b) shows a similar mechanism, except the $\mathrm{O}_{2}{ }^{-}$species are replaced by surface $\mathrm{O}^{-}$species. Accordingly, $\mathrm{HCHO}$ was oxidized into DOM first, then transformed into the formate via the oxygen migration. Both the processes were quick steps. After the consumption, the vacancies were formed and gaseous oxygen would dissociate at the vacancies resulting in $\mathrm{O}_{2}^{-}$species. Subsequently, DOM would transform into formate and one proton would migrate to $\mathrm{O}$ forming $-\mathrm{OH}$. The formate would react with $-\mathrm{OH}$ to obtain $\mathrm{CO}_{2}$ and $\mathrm{H}_{2} \mathrm{O}$. Finally, $\mathrm{Co}^{3+-} \mathrm{O}^{-}-\mathrm{Co}^{2+}$ is recovered to its initial form. During the entire process, the decomposition of

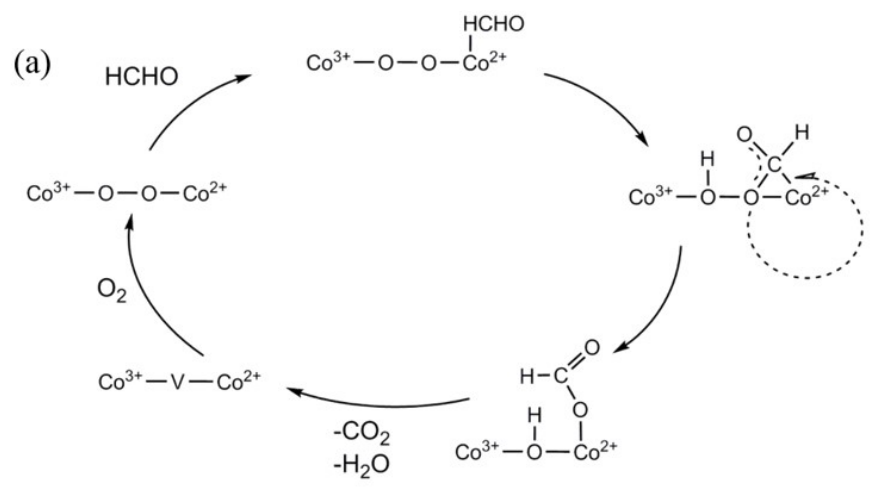

(b)

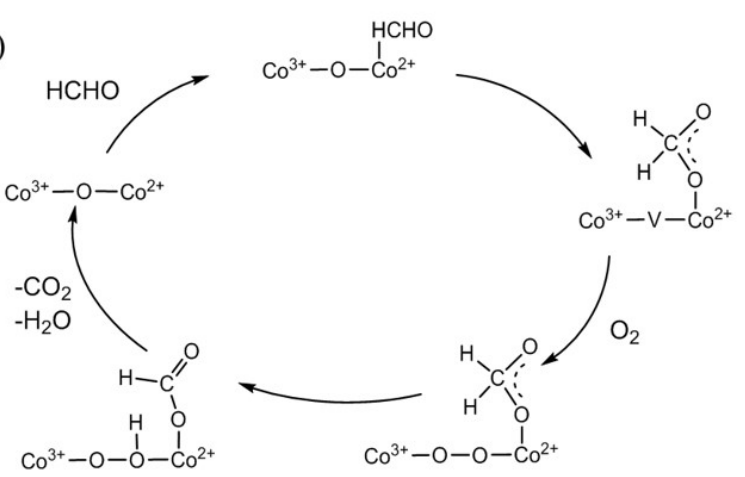

Fig. 9. Mechanism of enhanced $\mathrm{HCHO}$ conversion oxidized by (a) $\mathrm{O}_{2}^{-}$and (b) $\mathrm{O}^{-}$over Co-LDO(N). 
the formate is regarded as the rate-determining step according to the DRIFT. In summary, it can be speculated that the enhanced $\mathrm{HCHO}$ conversion ability was related to $\mathrm{Co}^{2+}-\mathrm{O}^{-}-\mathrm{Co}^{3+}$ and $\mathrm{Co}^{2+}-\mathrm{O}_{2}-\mathrm{Co}^{3+}$. Both octahedrally coordinated $\mathrm{Co}^{2+}$ and active oxygen species at the vacancies play important roles in this system. In addition, extra oxygen may over-oxidize the formate into carbonate, causing inactivation of the catalyst after long-time use.

\section{Conclusions}

A Co-LDO(N) catalyst, rich in extra octahedrally coordinated $\mathrm{Co}^{2+}$ ions and vacancies, was prepared by a hydrothermal method, and calcined in $\mathrm{N}_{2}$. The $\mathrm{N}_{2}$ calcined catalyst exhibited better $\mathrm{HCHO}$ oxidation ability than that calcined in $\mathrm{O}_{2}$. Relative characterizations proved that the octahedrally coordinated $\mathrm{Co}^{2+}$ ions are more open than the tetrahedrally coordinated $\mathrm{Co}^{2+}$ ions and more easy to oxidize. Furthermore, the $\mathrm{N}_{2}$ calcination process greatly increased the amount of active oxygen species and their mobility. The in situ DRIFTS indicated that HCHO would be adsorbed on the surface of the catalyst and $\mathrm{O}^{-}$ and $\mathrm{O}_{2}{ }^{-}$would oxidize the adsorbed $\mathrm{HCHO}$ molecule into DOM. Subsequently, DOM transformed into formate. The formate would finally decompose into $\mathrm{CO}_{2}$ and $\mathrm{H}_{2} \mathrm{O}$. The entire catalytic process occurred at $\mathrm{Co}^{3+}-\mathrm{O}_{2}--\mathrm{Co}^{2+}$ and $\mathrm{Co}^{3+}-\mathrm{O}^{-}-\mathrm{Co}^{2+}$.

\section{References}

[1] Z. X. Yan, Z. H. Xu, B. Cheng, C. J. Jiang, Appl. Surf. Sci., 2017, 404,
426-434.

[2] W. Cui, D. Xue, N. Tan, B. Zheng, M. Jia, W. Zhang, Chin. J. Catal., 2018, 39, 1534-1542.

[3] Z. Yan, Z. Xu, L. Yue, L. Shi, L. Huang, Chin. J. Catal., 2018, 39, 1919-1928.

[4] Y. Xia, L. Xia, Y. Liu, T. Yang, J. Deng, H. Dai, J. Environ. Sci., 2018, 64, 276-288.

[5] C. Zhang, F. Liu, Y. Zhai, H. Ariga, N. Yi, Y. Liu, K. Asakura, M. Flytzani-Stephanopoulos, H. He, Angew. Chem. Int. Ed., 2012, 51, 9628-9632.

[6] Y. Huang, B. Long, M. Tang, Z. Rui, M. S. Balogun, Y. Tong, H. Ji, Appl. Catal. B, 2016, 181, 779-787.

[7] B. B. Chen, C. Shi, M. Crocker, Y. Wang, A. M. Zhu, Appl. Catal. B, 2013, 132-133, 245-255.

[8] J. González-Prior, R. López-Fonseca, J. I. Gutiérrez-Ortiz, B. de Rivas, Appl. Catal. B, 2018, 222, 9-17.

[9] M. Zhou, L. Cai, M. Bajdich, M. García-Melchor, H. Li, J. He, J. Wilcox, W. Wu, A. Vojvodic, X. Zheng, ACS Catal., 2015, 5, 4485-4491.

[10] K. Omata, T. Takada, S. Kasahara, M. Yamada, Appl. Catal. A, 1996, $146,255-267$.

[11] S. P. Mo, S. D. Li, J. Q. Li, Y. Z. Deng, S. P. Peng, J. Y. Chen, Y. F. Chen, Nanoscale, 2016, 8, 15763-15773.

[12] C. Ma, D. Wang, W. Xue, B. Dou, H. Wang, Z. Hao, Environ. Sci. Technol., 2011, 45, 3628-3634.

[13] Y. Yu, T. Takei, H. Ohashi, H. He, X. Zhang, M. Haruta, J. Catal., 2009, 267, 121-128.

[14] L. Ma, D. S. Wang, J. H. Li, B. Y. Bai, L. X. Fu, Y. D. Li, Appl. Catal. B, 2014, 148-149, 36-43.

[15] L. H. Hu, Q. Peng, Y. D. Li, J. Am. Chem. Soc., 2008, 130, 16136-16137.

[16] S. Kuś, M. Otremba, A. Tórz, M. Taniewski, Appl. Catal. A, 2002, 230, 263-270.

\section{Graphical Abstract}

Chin. J. Catal., 2019, 40: 703-712 doi: S1872-2067(19)63273-0

Exploration of the active phase of the hydrotalcite-derived cobalt catalyst for HCHO oxidation

Mengya Lin, Xiaolin $\mathrm{Yu}^{*}$, Xueqin Yang, Xiuyun Ma, Maofa Ge*

Institute of Chemistry, Chinese Academy of Sciences; University of Chinese Academy of Sciences; Institute of Urban Environment, Chinese Academy of Sciences

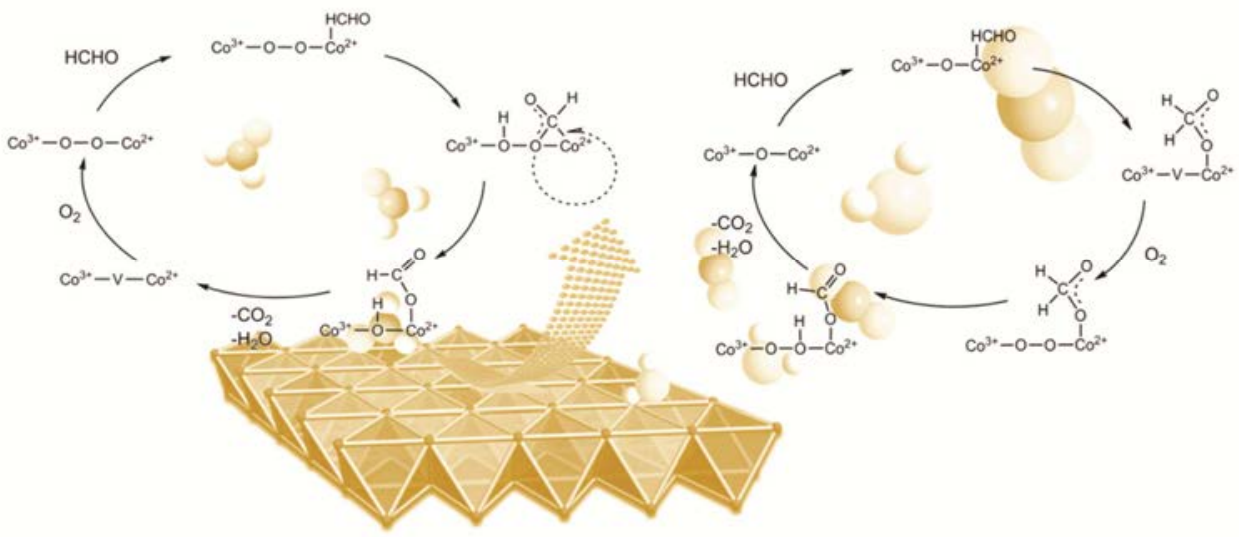

The $\mathrm{Co}_{3} \mathrm{O}_{4}$ catalyst calcined in $\mathrm{N}_{2}$ exhibited enhanced $\mathrm{HCHO}$ degradation ability. The enhanced activity was because of the extra octahedrally coordinated $\mathrm{Co}^{2+}$ ions and surface oxygen species, and the entire process occurred at $\mathrm{Co}^{2+-} \mathrm{O}^{-}-\mathrm{Co}^{3+}$ and $\mathrm{Co}^{2+}-\mathrm{O}_{2}^{-}-\mathrm{Co}^{3+}$. 
[17] A. E. Galetti, M. F. Gomez, L. A. Arrua, M. C. Abello, Appl. Catal. A, 2011, 408, 78-86.

[18] X. H. Zou, T. H. Chen, H. B. Liu, P. Zhang, Z. Y. Ma, J. J. Xie, Fuel, 2017, 190, 47-57.

[19] U. Chellam, Z. P. Xu, H. C. Zeng, Chem. Mater., 2000, 12, 650-658.

[20] Y. X. Li, S. S. Li, D. M. Xue, X. Q. Liu, M. M. Jin, L. B. Sun, J. Mater. Chem. A, 2018, 6, 8930-8939.

[21] Y. Xu, Z. Wang, L. Tan, H. Yan, Y. Zhao, H. Duan, Y. F. Song, Ind. Eng. Chem. Res., 2018, 57, 5259-5267.

[22] M. Lin, X. Yu, X. Yang, K. Li, M. Ge, J. Li, Catal. Sci. Technol., 2017, 7, 1573-1580.

[23] X. Zhang, H. Li, X. Lv, J. Xu, Y. Wang, C. He, N. Liu, Y. Yang, Y. Wang, Chem.-Eur. J., 2018, 24, 8822-8832.

[24] H. Shin, W.J. Lee, J. Mater. Chem. A, 2016, 4, 12263-12272.

[25] L. H. Hu, K. Q. Sun, Q. Peng, B. Q. Xu, Y. D. Li, Nano Res., 2010, 3, 363-368.

[26] B. de Rivas, R. Lopez-Fonseca, C. Jimenez-Gonzalez, J. I. Gutierrez-Ortiz, J. Catal., 2011, 281, 88-97.

[27] Z. Chen, L. Cai, X. Yang, C. Kronawitter, L. Guo, S. Shen, B. E. Koel, ACS Catal., 2018, 8, 1238-1247.

[28] Z. Y. Pu, H. Zhou, Y. F. Zheng, W. Z. Huang, X. N. Li, Appl. Surf. Sci., 2017, 410, 14-21.

[29] Q. Zhang, S. P. Mo, B. X. Chen, W. X. Zhang, C. L. Huang, D. Q. Ye, Mol. Catal., 2018, 454, 12-20.

[30] H. Zhang, C. Wang, H. L. Sun, G. Fu, S. Chen, Y. J. Zhang, B. H. Chen, J. R. Anema, Z. L. Yang, J. F. Li, Z. Q. Tian, Nat. Commun., 2017, 8, 15447.

[31] Z. Wang, W. Wang, L. Zhang, D. Jiang, Catal. Sci. Technol., 2016, 6, 3845-3853.

[32] W. Wang, Q. Zhu, F. Qin, Q. Dai, X. Wang, Chem. Eng. J., 2018, 333, 226-239.

[33] D. Gu, C.J. Jia, C. Weidenthaler, H.J. Bongard, B. Spliethoff, W. Schmidt, F. Schüth, J. Am. Chem. Soc., 2015, 137, 11407-11418.
[34] S. Mo, S. Li, W. Li, J. Li, J. Chen, Y. Chen, J. Mater. Chem. A, 2016, 4, 8113-8122.

[35] Q. Fu, W. X. Li, Y. X. Yao, H. Y. Liu, H. Y. Su, D. Ma, X. K. Gu, L. M. Chen, Z. Wang, H. Zhang, B. Wang, X.H. Bao, Science, 2010, 328, 1141-1144.

[36] J. Wang, G. Zhang, P. Zhang, J. Mater. Chem. A, 2017, 5, 5719-5725.

[37] G. X. Chen, Y. Zhao, G. Fu, P. N. Duchesne, L. Gu, Y. P. Zheng, X. F. Weng, M. S. Chen, P. Zhang, C. W. Pao, J. F. Lee, N. F. Zheng, Science, 2014, 344, 495-499.

[38] Y. Wang, Y. Zhang, Z. Liu, C. Xie, S. Feng, D. Liu, M. Shao, S. Wang, Angew. Chem. Int. Ed., 2017, 56, 5867-5871.

[39] X. Q. Yang, X. L. Yu, M. Y. Lin, M. F. Ge, Y. Zhao, F. Y. Wang, J. Mater. Chem. A, 2017, 5, 13799-13806.

[40] C. Wang, C. H. Zhang, W. C. Hua, Y. L. Guo, G. Z. Lu, S. Gil, A. Giroir-Fendler, Chem. Eng. J., 2017, 315, 392-402.

[41] X. Weng, P. Sun, Y. Long, Q. Meng, Z. Wu, Environ. Sci. Technol., 2017, 51, 8057-8066.

[42] L. Zhu, J. Wang, S. Rong, H. Wang, P. Zhang, Appl. Catal. B, 2017, 211, 212-221.

[43] Y. C. Huang, K. H. Ye, H. B. Li, W. J. Fan, F. Y. Zhao, Y. M. Zhang, H. B. Ji, Nano Res., 2016, 9, 3881-3892.

[44] W. Tang, W. Xiao, S. Wang, Z. Ren, J. Ding, P. X. Gao, Appl. Catal. B, 2018, 226, 585-595.

[45] B. B. Chen, X. B. Zhu, M. Crocker, Y. Wang, C. Shi, Catal. Commun., 2013, 42, 93-97.

[46] B. Bai, J. Li, ACS Catal., 2014, 4, 2753-2762.

[47] H. C. Wu, T. C. Chen, Y. C. Chen, J. F. Lee, C. S. Chen, J. Catal., 2017, 355, 87-100.

[48] H. Chen, M. Tang, Z. Rui, H. Ji, Ind. Eng. Chem. Res., 2015, 54, 8900-8907.

[49] F. Liu, J. Shen, D. Xu, W. Zhou, S. Zhang, L. Wan, Chem. Eng. J., 2018, 334, 2283-2292.

\title{
钴基水滑石衍生物催化甲醛氧化活性成分的探究
}

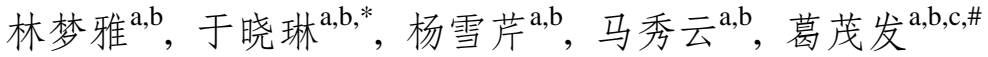 \\ a中国科学院化学研究所分子动态与稳态结构国家重点实验室, 北京分子科学国家研究中心, \\ 中国科学院分子科学科教融合卓越创新中心, 北京100190 \\ ' 中国科学院大学, 北京100049 \\ c中国科学院城市环境研究所, 中国科学院区域大气环境研究卓越创新中心, 福建廈门361021
}

摘要: 甲醛是一种常见的室内污染气体, 可对人类健康产生极大危害. 如何高效环保地去除甲醛已成为亟待解决的问题. 催化氧化降解法去除甲醛由于其高效、持久、产物清洁环保而被广泛研究. 催化氧化法要求催化剂在反应过程中具有良 好的氧化还原特性, 因此, 一般采用拥有多重价态的过渡金属氧化物作为催化剂材料. 近年来, 钴氧化物由于拥有多种价 态且来源广泛, 被广泛用于催化领域. 目前已有关于钴基氧化物改性方面的研究报道. 此外, 许多关于钴基氧化物活性机 理的研究也开展. 这些研究对新催化材料的合成具有十分重要的指导意义.

本文通过在空气氛围和氮气氛围中对钴基水滑石进行制烧, 得到了不同的衍生材料. 利用氢气程序升温还原、X射线 光电子能谱(XPS)、高分辨透射电镜、扫描电镜、比表面分析及拉曼光谱等表征手段发现, 在氮气氛围中炦烧的材料, 其表 面含有更多的八配位二价钴以及表面活性氧物种, 更有利于在反应过程中氧化甲醛分子, 并更容易解离空气中的氧气分 子. 此外, 还利用原位红外光谱对反应过程进行了表征, 由氮气䍩烧得到的钴基材料在甲醛催化降解过程中遵循M-K机理, 甲醛分子首先由表面活性氧物种 $\left(\mathrm{O}_{2}^{-}, \mathrm{O}^{-}\right)$氧化为中间体亚甲二氧基(DOM), 之后该中间体转化为甲酸盐物种, 后者进一步 分解生成最终产物 $\mathrm{H}_{2} \mathrm{O}$ 和 $\mathrm{CO}_{2}$. 在该过程中, 甲酸盐分解为控速步骤.

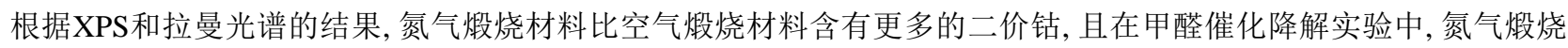
材料表现出更好的转化能力. 二价钴通常被认为是惰性的, 并不具备催化氧化甲醛的活性. 然而在本体系中, 氮气段烧材 料表面含有一种八配位的二价钴, 该配位环境与传统的活性三价钴的配位环境相同. 此外, 该二价钴拥有更高的表面能且 
更容易与氧气接触. 另一方面, 氮气煅烧材料表面含有更多的表面活性氧物种, 能够提高材料的氧化还原能力. 因此我们 推测, 在本文体系中, 氮气煅烧材料能够拥有更好的活性主要是由于存在 $\mathrm{Co}^{2+}-\mathrm{O}^{-}-\mathrm{Co}^{3+}$ 和 $\mathrm{Co}^{2+}-\mathrm{O}_{2}{ }^{-}-\mathrm{Co}^{3+}$ 这两种成分.

在利用原位红外表征手段对反应中间过程进行探究时, 为了证明氧的重要作用, 我们分别向催化剂表面通入甲醛+氮 气和甲醛 + 氧气 + 氮气两种气流. 结果显示, 在有氧气参与的过程中, 主要产物为甲酸盐和碳酸盐, 而在没有氧气参与的过 程中, 在催化剂表面观察到DOM、碳酸盐、甲酸盐和甲醛的吸附峰. 这说明有氧气参与时催化剂能够快速地将甲酫氧化, 而 在不通入氧气的情况下, DOM先快速生成, 之后有甲酸盐生成. 这说明氧气将甲醛先氧化为DOM, 再进一步转化为甲酸盐. 甲酸盐的分解较慢, 不断累积, 导致在氧气充足的情况下, 依旧可以观察到材料表面大量的甲酸盐. 因此, 甲酸盐的分解为 该体系的控速步骤.

关键词: 甲醛; 水滑石衍生物; 活性相; 钴氧化物

收稿日期: 2018-10-17. 接受日期: 2018-12-05. 出版日期: 2019-05-05.

*通讯联系人. 电话/传真: (010)62554518; 电子信箱: gemaofa@iccas.ac.cn

\#通讯联系人. 电话/传真: (010)62554518; 电子信箱: icecoolyu@iccas.ac.cn

基金来源: 国家自然科学基金(91544227, 21777166); 国家重点研发计划(2016YFC0202202).

本文的电子版全文由Elsevier出版社在ScienceDirect上出版(http://www.sciencedirect.com/science/journal/18722067). 